\title{
Recent Nonfarm Employment Growth and the Black Population in the Nonmetro South
}

\author{
David Weisblat and Fred Hines*
}

INTRODUCTION

During the 1950's and 1960's, the Nation's nonmetropolitan areas experienced massive outmigration. This stemmed largely from declining job opportunities in agriculture which were only partly offset by increased job opportunities in other industries. Economic decline and distress were particularly acute in the nonmetropolitan counties of the South with large Black populations. The massive outmigration of Blacks that began in the 1930 's and reached a peak in the 1960's left many rural, predominately Black counties of the Mississippi Delta, the Black Belt of Alabama and Georgia and the Piedmont of North and South Carolina with smaller populations and fewer jobs in 1970 than 30 years earlier. During the 1970's, however, the flow of nonmetro outmigrants subsided and nonmetro areas began to grow more rapidly than metro areas (Beale, 1975, 1978, 1981). In nonmetro areas of the South, population grew by 17.1 percent in the 1970 's. This was over 50 percent faster than the national rate and represented almost half of nonmetro population growth nationwide. This reversal of population growth trends was in part brought about by increasing nonfarm job opportunities. Nonfarm employment in the nonmetro South grew by 29.8 percent between 1969 and 1979 (Bluestone).

Despite the general upward trend in population and jobs in Southern nonmetro areas, questions still remain as to how well Southern counties with large Black populations have fared in attracting jobs and retaining population. There has been much speculation that these counties have been bypassed by the nonmetro expansion in job opportunities.

Recently available data from the Census of Population, 1980 indicate that predominately Black nonmetro counties of six Southern States ${ }^{1}$ experienced only slight population growth (2.2 percent) in the 1970 's. This compares favorably with the declines of approximately 10 percent in the three preceding decades (Table 1), but is miniscule when compared with 27.3 percent increase in counties which are less than 10 percent Black. Also, data from the Bureau of Economic Analysis show that while counties with a

*Regional Analysis_ Community Resources, Econ. Dev. Div., Econ. Research Service, USDA, Washington, DC. 
TABLE 1

Population and population change in nonmetro counties of six southern states, ${ }^{1}$ by percent black, $1940-80$

\begin{tabular}{|c|c|c|c|c|c|c|}
\hline \multirow[b]{2}{*}{ Item } & \multirow{2}{*}{$\begin{array}{c}\text { All } \\
\text { counties }\end{array}$} & \multicolumn{4}{|c|}{ Percent black, 1970} & \multirow[b]{2}{*}{$\begin{array}{c}50.0 \text { percent } \\
\text { and over }\end{array}$} \\
\hline & & $\begin{array}{l}\text { Less than } \\
10 \text { percent }\end{array}$ & $\begin{array}{c}10.0-19.9 \\
\text { percent }\end{array}$ & $\begin{array}{c}20.0-33.2 \\
\text { percent }\end{array}$ & $\begin{array}{c}33.3-49.9 \\
\text { percent }\end{array}$ & \\
\hline \multicolumn{7}{|c|}{ Percent change in total population: } \\
\hline $1940-1950$ & -2.0 & -2.8 & 2.4 & 2.0 & -3.1 & -8.1 \\
\hline $1950-1960$ & -2.2 & -8.3 & 4.8 & 2.5 & -2.9 & -9.2 \\
\hline $1960-1970$ & 3.4 & 13.6 & 15.5 & 3.7 & -0.5 & -10.2 \\
\hline $1970-1980$ & 14.7 & 27.3 & 21.3 & 13.9 & 11.1 & 2.2 \\
\hline
\end{tabular}

Source: Census of Population.

'Alabama, Arkansas, Georgia, Louisiana, Mississippi and South Carolina 
Nonfarm Wage and Salary Employment Growth in Nonmetro Counties of Six Southern States, by Percent Black 1969-79

\begin{tabular}{|c|c|c|c|c|c|c|}
\hline \multirow[b]{2}{*}{ Item } & \multirow{2}{*}{$\begin{array}{c}\text { All } \\
\text { counties }\end{array}$} & \multicolumn{4}{|c|}{ Percent black, 1970} & \multirow[b]{2}{*}{$\begin{array}{c}50.0 \text { percent } \\
\text { and over }\end{array}$} \\
\hline & & $\begin{array}{l}\text { Less than } \\
10 \text { percent }\end{array}$ & $\begin{array}{c}10.0-19.9 \\
\text { percent }\end{array}$ & $\begin{array}{c}20.0-33.2 \\
\text { percent }\end{array}$ & $\begin{array}{c}33.3-49.9 \\
\text { percent }\end{array}$ & \\
\hline \multirow[t]{2}{*}{$\begin{array}{l}\text { Nonfarm wage and salary } \\
\text { employment, } 1979 \\
\text { (thousands) }\end{array}$} & $3,565.9$ & 531.0 & 679.2 & 1146.6 & 789.6 & 419.6 \\
\hline & \multicolumn{6}{|c|}{ Percent of nonfarm wage and salary employment, 1979} \\
\hline $\begin{array}{l}\text { Total nonfarm wage and salary } \\
\text { Goods producing industries } \\
\text { Service producing industries }\end{array}$ & $\begin{array}{l}100.0 \\
39.2 \\
60.8\end{array}$ & $\begin{array}{r}100.0 \\
43.8 \\
56.2\end{array}$ & $\begin{array}{r}100.0 \\
40.5 \\
59.5\end{array}$ & $\begin{array}{r}100.0 \\
38.8 \\
61.2\end{array}$ & $\begin{array}{r}100.0 \\
38.4 \\
61.6\end{array}$ & $\begin{array}{r}100.0 \\
33.5 \\
66.5\end{array}$ \\
\hline Service producing industries & \multicolumn{6}{|c|}{ Percent change in employment 1969-1973 } \\
\hline $\begin{array}{l}\text { Total nonfarm wage and salary } \\
\text { Goods producing industries } \\
\text { Service producing industries }\end{array}$ & $\begin{array}{l}12.4 \\
14.8 \\
10.8\end{array}$ & $\begin{array}{l}20.4 \\
20.1 \\
20.7\end{array}$ & $\begin{array}{r}9.5 \\
17.9 \\
4.1\end{array}$ & $\begin{array}{l}11.9 \\
12.1 \\
11.8\end{array}$ & $\begin{array}{l}12.3 \\
13.3 \\
11.7\end{array}$ & $\begin{array}{r}9.2 \\
12.0 \\
8.0\end{array}$ \\
\hline Service producing industries & \multicolumn{6}{|c|}{ Percent change in employment 1973-1979 } \\
\hline $\begin{array}{l}\text { Total nonfarm wage and salary } \\
\text { Goods producing industries } \\
\text { Service producing industries }\end{array}$ & $\begin{array}{l}14.5 \\
12.1 \\
16.1\end{array}$ & $\begin{array}{l}16.9 \\
12.4 \\
20.7\end{array}$ & $\begin{array}{l}15.9 \\
10.5 \\
19.0\end{array}$ & $\begin{array}{l}14.6 \\
10.5 \\
17.4\end{array}$ & $\begin{array}{l}14.8 \\
13.0 \\
16.0\end{array}$ & $\begin{array}{r}9.3 \\
18.1 \\
5.3\end{array}$ \\
\hline Service producing industries & \multicolumn{6}{|c|}{ Percent change in employment 1969-1979 } \\
\hline $\begin{array}{l}\text { Total nonfarm wage and salary } \\
\text { Goods producing industries } \\
\text { Service producing industries }\end{array}$ & $\begin{array}{l}28.6 \\
28.6 \\
28.6\end{array}$ & $\begin{array}{l}40.8 \\
35.0 \\
45.7\end{array}$ & $\begin{array}{l}26.4 \\
30.3 \\
23.9\end{array}$ & $\begin{array}{l}28.3 \\
23.9 \\
31.2\end{array}$ & $\begin{array}{l}30.0 \\
28.1 \\
29.6\end{array}$ & $\begin{array}{l}19.3 \\
32.2 \\
13.7\end{array}$ \\
\hline Service producing industries & \multicolumn{6}{|c|}{ Percent of change in nonfarm wage and salary employment 1969-1979 } \\
\hline Total nonfarm wage and salary & 100.0 & 100.0 & 100.0 & 100.0 & 100.0 & 100.0 \\
\hline Goods producing industries & 39.1 & 39.1 & 45.0 & 34.0 & 37.5 & 50.4 \\
\hline Service producing industries & 60.9 & 60.9 & 55.0 & 66.0 & 62.5 & 49.6 \\
\hline
\end{tabular}


population 50 percent or more Black experienced a 19.3 percent growth in nonfarm wage and salary employment, in counties with a population less than 10 percent Black employment grew more than twice as fast (Table 2).

This study attempts to explain the differences in employment growth among southern nonmetro counties having predominately White populations and predominately Black populations. Is the prevalence of Blacks in the population the key factor in explaining lower employment growth? Does industry bypass a county just because it has a relatively large Black population? Do other factors account for the differences in growth rates? Can the less vigourous growth of Black counties be explained by human resources problems, including lower educational levels, a population structure heavily weighted toward the young and old as opposed to the working age, low labor force participation, or low skill levels? What part do differences in county infrastructure (highways, air service) play in explaining differences in county growth rates? Finally, does the presence of a state college or the proportion of the population that is retired help explain differences among nonmetro counties in economic growth?

\section{DATA}

The unit of analysis is the county. Nonmetropolitan counties are those counties not designated as being within an SMSA as of 1974. Employment data was obtained from the Bureau of Economic Analysis, U.S. Department of Commerce. Population and human resource data come from the Census of Population, 1970 and from preliminary data from the Census of Population, 1980.

\section{REVIEW OF RELATED STUDIES}

Beale (1977a) found that in 1975, 17.1 percent of the Black nonmetro labor force in the South was unemployed. The comparable White unemployment rate was 8.3 percent. Till, focusing on the employment of rural minorities during the sixties and seventies, found that between 1959 and 1969 total nonfarm employment grew at an annual average rate of 3.5 percent in 154 nonmetro counties in which more than 50 percent of the population was minority and at 4.1 percent in 476 nonmetro counties in which less than 10 percent of the population was minority. He found the comparable rates for 1969-77 were 2.5 percent and 3.5 percent.

Other studies also reveal that when growth comes to rural areas with large Black populations, White residents benefit more than Black residents. Using 215 Southeastern nonmetro counties which had 5000 or more Blacks in 1950, Kain and Persky found that Blacks gained only 21 percent of the increase in nonfarm jobs during the 1950's while they comprised 43 percent of the population. In a similar study, based on 1960 and 1970 population data, Walker (1975) found that Blacks received only 16 percent of the increase in nonfarm employment and yet were 40 percent of the population. 
A later study by Walker (1979) used regression analysis to explain employment growth in 244 nonmetro Southern counties with 5000 or more Blacks in 1960. Using the per capita change in what was termed modern sector employment, that is, nonagricultural employment minus personal service employment, as the dependent variable, and regressing that on the proportion of the population that was Black in 1960, he found that the higher the proportion Black, the smaller the per capita growth in modern sector employment. Walker than tested to see if lagging growth in heavily Black areas was a result of racial discrimination on the part of employers in making location decisions or was the result of other characteristics of the area. The results of this regression indicated that the proportion of the population that was Black was still an important negative influence on employment growth, however, other variables, especially labor force skill levels, were important. Walker concluded that while discrimination was a problem, the most pressing issue was to overcome Black/White differences in labor force skill levels.

This study follows up the work by Walker. We have expanded the study to include all nonmetro counties of the states involved. ${ }^{2}$ This better represents growth in the rural South than does Walker's group of counties with 5000 or more Blacks. Our study is about twice as large as his and also, lets us look at differences between counties that are heavily Black ( 50 percent or more) and those with a small proportion of Blacks ( 10 percent or less).

\section{THE TREND-AN OVERVIEW}

Nonfarm wage and salary employment increased 28.6 percent in the study counties between 1969 and 1979, a period which covered two complete business cycles (Table 2 ). While the nonmetro counties where the proportion of Blacks ranged between 10 and 50 percent experienced approximately the same rate of growth as the average for the sample, the growth rate for those counties less then 10 percent Black was much higher than average while the growth rate for those counties more than 50 percent Black was much lower than average. Variation in growth rates was greater in service producing industries than in goods producing industries.

Growth in service producing industries ranged from 13.7 percent in counties with the highest proportion of Blacks to 45.7 percent in counties with the lowest proportion of Blacks. On the other hand, growth rates in the goods producing industries ranged only from 23.9 percent to 35.0 percent. During the decade the goods producing industries became more important in the highly Black counties and the service producing industries became more important in counties with the fewest Blacks.

A negative association between the prevalence of Blacks and employment growth was observed in both the 1969-73 and 1973-79 business cycle. However, the structure of employment growth across counties grouped by the prevalence of Blacks changed between 1969-73 and 1973-79. The most significant difference was the reversal of the relative growth rates in goods producing industries. In the later period, the counties which were 
Matrix of Correlation Coefficients of Selected Variables, Nonmetro Counties of Six Southern States

\begin{tabular}{|c|c|c|c|c|c|c|c|c|c|c|c|c|c|}
\hline & y & $\mathrm{X}_{1}$ & $\mathrm{X}_{2}$ & $\mathrm{X}_{3}$ & $\mathrm{X}_{4}$ & $\mathrm{X}_{5}$ & $\mathrm{X}_{6}$ & $\mathrm{X}_{7}$ & $\mathrm{X}_{8}$ & $\mathrm{X}_{9}$ & $\mathrm{X}_{10}$ & $\mathrm{X}_{11}$ & $\mathrm{X}_{12}$ \\
\hline$y$-Employment growth, 1969-79 & 1.000 & & & & & & & & & & & & \\
\hline $\mathrm{X}_{1}$-Percent Black, 1970 & -.358 & 1.000 & & & & & & & & & & & \\
\hline \multicolumn{14}{|l|}{$\begin{array}{l}\text { Human resources; 1970: } \\
\quad \mathrm{X}_{2} \text { - Percent with less than } 12\end{array}$} \\
\hline $\begin{array}{c}X_{2}-\text { Percent with less than } 12 \\
\text { years of schooling }\end{array}$ & -.344 & .223 & 1.000 & & & & & & & & & & \\
\hline $\mathrm{X}_{3}$-Female labor force & & & & & & & & & & & & & \\
\hline participation & .121 &.-024 & -.030 & 1.000 & & & & & & & & & \\
\hline $\mathrm{X}_{4}$-Male labor force participation & .212 & -.131 & -.060 & .550 & 1.000 & & & & & & & & \\
\hline $\begin{array}{l}\mathrm{X}_{5} \text {-Percent of population } 16-64 \\
\text { years old }\end{array}$ & .368 & -.605 & -.370 & .433 & .197 & 1.000 & & & & & & & \\
\hline \multirow{2}{*}{\multicolumn{14}{|c|}{$\begin{array}{l}\text { Infrastructure: } \\
\quad \mathrm{X}_{6} \text {-Presence of interstate highway }\end{array}$}} \\
\hline & & & & & & & & & & & & & \\
\hline$(0,1)^{1}$ & -.022 & .008 & -.167 & .186 & .130 & .168 & 1.000 & & & & & & \\
\hline$X_{7}$-Presence of air service $(0,1)^{2}$ & .316 & -.083 & -.439 & .097 & .187 & .214 & -.001 & 1.000 & & & & & \\
\hline Others: & & & & & & & & & & & & & \\
\hline $\mathrm{X}_{8}$ - Percent urban, 1970 & .212 & .002 & -.473 & .313 & .267 & .261 & .175 & .389 & 1.000 & & & & \\
\hline $\mathrm{X}_{9}$-Percent employed in & & & & & & & & & & & & & \\
\hline agriculture, 1970 & -.242 & .272 & .435 & -.280 & -.216 & -.483 & -.166 & -.170 & -.266 & 1.000 & & & \\
\hline $\mathrm{X}_{10}$-large number of retirees ${ }^{3}(0,1)$ & .183 & -.321 & -.173 & -.086 & -.197 & .133 & -.033 & .122 & -.072 & -.040 & 1.000 & & \\
\hline $\begin{array}{l}X_{11} \text {-Presence of senior state col- } \\
\text { lege }(0,1)\end{array}$ & .170 & -.010 & -.377 & .148 & -.050 & .360 & .106 & .260 & .307 & -.152 & .099 & 1.000 & \\
\hline $\mathrm{X}_{12}-\mathrm{Log}$ of distance of nearest & & & & & & & & & & & & & \\
\hline SMSA & -.076 & -.101 & -.074 & .051 & -.154 & -.023 & -.132 & .122 & -.006 & .129 & .150 & .018 & 1.000 \\
\hline
\end{tabular}

'Existence of an interstate highway at least 25\% complete in 1970.

${ }^{2}$ Existence of commercial air services.

${ }^{3}$ Counties of at least 15 percent net immigration of persons 60 years or older between 1960 and 1970 
TABLE 4

Means of Human Resource and Infrastructure Variables,

Nonmetro Counties of Six Southern States, by

Percent Black

\begin{tabular}{|c|c|c|c|c|c|}
\hline \multirow[b]{2}{*}{ Item } & \multicolumn{5}{|c|}{ Percent black, 1970} \\
\hline & $\begin{array}{l}\text { Less than } \\
10 \text { percent }\end{array}$ & $\begin{array}{c}10.0-19.9 \\
\text { percent }\end{array}$ & $\begin{array}{c}20.0-33.2 \\
\text { percent }\end{array}$ & $\begin{array}{l}33.3-49.9 \\
\text { percent }\end{array}$ & $\begin{array}{l}50.0 \text { percent } \\
\text { or more }\end{array}$ \\
\hline \multicolumn{6}{|l|}{$\begin{array}{l}\text { Human resources; 1970: } \\
\text { Percent with less than } 12\end{array}$} \\
\hline years of schooling & 69.1 & 66.9 & 67.3 & 69.4 & 73.2 \\
\hline Female labor force participation & 35.7 & 37.9 & 38.8 & 38.5 & 35.5 \\
\hline Male labor force participation & 66.8 & 72.3 & 70.7 & 69.6 & 65.2 \\
\hline $\begin{array}{l}\text { Percent of population } 16-64 \\
\text { years old }\end{array}$ & 58.2 & 58.0 & 57.0 & 55.5 & 52.6 \\
\hline \multicolumn{6}{|l|}{ Infrastructure: } \\
\hline $\begin{array}{l}\text { Presence of interstate highway } \\
(0,1)^{1}\end{array}$ & .15 & .27 & .23 & .26 & .15 \\
\hline Presence of air service $(0,1)^{1}$ & .06 & .10 & .16 & .06 & .03 \\
\hline \multicolumn{6}{|l|}{ Others: } \\
\hline Percent urban, 1970 & 19.2 & 30.0 & 34.3 & 30.8 & 21.1 \\
\hline $\begin{array}{l}\text { Percent employed in } \\
\text { agriculture, } 1970\end{array}$ & 9.8 & 8.1 & 9.2 & 10.6 & 15.7 \\
\hline Large number of retirees $(0,1)^{1}$ & .36 & .00 & .01 & .05 & .00 \\
\hline Presence of senior state college & & & & & \\
\hline$(0,1)$ & .07 & .04 & .09 & .09 & .06 \\
\hline Log of distance to nearest SMSA & 3.9 & 3.8 & 3.9 & 3.8 & 3.8 \\
\hline
\end{tabular}

'See Table 3. 
less than 10 percent Black grew the slowest while in the earlier period Black dominated counties grew the slowest. The growth patterns in the service producing sectors were about the same in both periods.

\section{EXPLAINING EMPLOYMENT GROWTH}

Correlation and OLS regression analysis are used to help explain the variations in employment growth among nonmetro counties in the South. Particular emphasis is placed on the significance of the prevalence of Blacks as a factor in explaining growth. Does the negative association between the percent of the population that is Black and employment growth shown in Table 2 result from intercounty racial differences or does it result from intercounty variations in the quality of human resources and infrastructure?

Human resource variables used to study employment growth included: percent of the adult population with less than 12 years of schooling, female and male labor force participation rates, and the percent of the population of working age (16-64 years). A well educated population is generally viewed as an inducement for employment growth since even in lower skilled jobs a high school education is often required or looked upon favorably by employers. It is hypothesized that a large percentage of the population without high school diplomas would deter county job growth. Higher labor force participation rates, indicating past involvement in the work force, are viewed as indicators of the willingness of the population to aggressively seek new job opportunities. High labor force participation rates, both for male and females, are hypothesized to attract industry. Likewise, a large proportion of a county's population of working age (in contrast to high percentages of young and old people) indicating a large potential labor force, is viewed as a positive factor in attracting more jobs.

Infrastructure variables such as interstate highways and air service are widely thought to be inducements to new industry since they provide greater market accessability hypothesized to be positively associated with growth of new jobs. They are included here along with the presence of Senior State Colleges and large retirement populations. Beale (1973) found that the presence of either a State College or a retirement community was a positive influence on nonmetro population growth. The presence of colleges and large numbers of retirees are therefore hypothesized to be positive inducements to employment growth.

A large percentage of population living in urban places is often used as an indicator of the availability and readiness of the population for nonfarm job opportunities and is hypothesized as positively related to employment growth. In contrast, a high percentage of persons employed in agriculture is generally associated with a labor pool lacking an employment history in nonfarm jobs. It is also used as an indicator of dominance of commercial agriculture. Both indicators are generally hypothesized to be negative influences on attracting nonfarm jobs. 
Distance to the nearest SMSA is also included in the analysis of factors affecting employment. Close proximity to metro areas is hypothesized as being viewed by industry as a positive attribute when selecting a plant site because it insures better access to inputs and product markets.

A matrix of simple correlations is shown in Table 3 and the means of the potential explanatory variables by counties grouped by the prevalence of Blacks (as in Tables 1 and 2) are shown in Table 4 . The correlation coefficients of employment change per 100 population with the potential explanatory variables are surprisingly low. The percent of the population of working age $\left(\mathrm{X}_{5}\right)$ is the most highly correlated with employment growth $(.368)$, and is followed by percent Black $\left(\mathrm{X}_{1}\right),(-.358)$, the education variable $\left(\mathrm{X}_{2}\right)(-.344)$, and the 0,1 variable indicating the presence of air service in the county $\left(\mathrm{X}_{7}\right)(.316)$. The coefficients measuring the association between percent Black and other variables indicate that percent Black was most strongly associated with percent of working age population (-.605), presence of large numbers of retirees $\left(\mathrm{X}_{10}\right)(-.321)$, a large percentage of persons with less than 12 years of schooling (.223), and a high percentage of work force employed in agriculture $\left(\mathrm{X}_{9}\right)(.272)$.

These measures of association and the means of counties grouped by percent Black (Table 4) strongly indicate that consideration of the differences in quality of human resources and infrastructure will not greatly alter the effect of prevalence of Blacks on employment growth. The regression results (Table 5) examine this further.

\section{Nonfarm Wage and Salary Employment, 1969-79}

Ordinary least squares (OLS) regression indicates that inter county racial difference was an important variable in explaining employment growth even after controlling for the quality of human resources available and local infrastructure. Between 1969 and 1979 the percent of the population that was Black had a statistically significant negative influence on total nonfarm wage and salary employment growth per hundred (Table 5). Ceteris paribus, there would be 2.6 fewer jobs per hundred created in a county 50 percent Black than in a county 10 percent Black. Since the average county had a population of 22740 in 1970, this would mean a difference of 591 jobs. Of the other 11 variables hypothesized to have an effect on employment growth, six had statistically significant coefficients. These were the percent with less then 12 years of school, the male force participation rate, the log of the distance to the nearest SMSA, and the dummies for the existence of air service, a large number of retirees, and an interstate highway.

In contrast to our expectations, the presence of an interstate highway had a negative influence on employment growth. However, this result is consistent with findings by Miller that the role of interstates in expanding growth may not have been very great during the 1970's. He found that "the average annual growth of total employment, 1967 to 1971, was higher in the interstate counties of each of the four census regions, while over the 1971 to 1975 period the rate of growth was either lower or, as in the South and West, almost equaled the rate in non-interstate counties." 
TABLE 5

Regression Analysis Explaining Employment Growth, Nonmetro Counties of Six Southern States

\begin{tabular}{|c|c|c|c|c|c|}
\hline & Dependent vari & ble: employme & $t$ growth per $100 \mathrm{p}$ & opulation in 19 & \\
\hline & $\begin{array}{c}\text { Total wage } \\
\text { and salary, } \\
1969-79\end{array}$ & $\begin{array}{c}\text { Service } \\
\text { industries, } \\
1969-79 \\
\end{array}$ & $\begin{array}{c}\text { Good-producing } \\
\text { industries, } \\
1969-79 \\
\end{array}$ & $\begin{array}{c}\text { Total wage } \\
\text { and salary, } \\
1969-73 \\
\end{array}$ & $\begin{array}{c}\text { Total wage } \\
\text { and salary } \\
1973-79 \\
\end{array}$ \\
\hline Intercept & 6.940 & .338 & 6.602 & 7.574 & -.633 \\
\hline $\mathrm{X}_{1}$-Percent black, $1970^{2}$ & $-.065 * * *$ & $-.039 * * *$ & $-.027 * *$ & $-.055 * * *$ & -.011 \\
\hline Human resource, 1970: & & & & & \\
\hline $\begin{array}{l}\mathrm{X}_{2} \text { - Percent with less than } 12 \text { years of } \\
\text { school }\end{array}$ & $-.140 * * *$ & $-.069 * *$ & $-.071^{* *}$ & $-.058^{* *}$ & $-.082 * *$ \\
\hline $\mathrm{X}_{3}$-Female labor force participation ${ }^{2}$ & .002 & .020 & -.018 & $.128^{* * *}$ & $-.126 * * *$ \\
\hline $\mathrm{X}_{4}$-Male labor force participation ${ }^{2}$ & $.106^{* *}$ & .020 & $.085^{* * *}$ & -.022 & $.127 * * *$ \\
\hline $\begin{array}{l}\mathrm{X}_{5} \text { - Percent of population } 16-64 \text { years } \\
\text { old }^{2}\end{array}$ & .222 & $.187 * *$ & .035 & -.037 & $.259 * *$ \\
\hline Infrastructure: & & & & & \\
\hline $\begin{array}{c}X_{6} \text { - Presence of interstate highway } \\
(0,1)^{12}\end{array}$ & $-1.383 * *$ & -.306 & $-1.077 * *$ & -.061 & $-1.322 * *$ \\
\hline $\mathrm{X}_{7}$-Presence of air service $(0,1)^{1}$ & $4.283^{* * *}$ & $3.753 * * *$ & .530 & $1.492 * * *$ & $2.791 * * *$ \\
\hline Others: & & & & & \\
\hline $\mathrm{X}_{8}$-Percent urban, 1970 & .005 & .006 & -.001 & .001 & .005 \\
\hline $\begin{array}{l}\mathrm{X}_{9} \text {-Percent employed in agriculture, } \\
1970\end{array}$ & .009 & -.010 & .019 & .029 & .019 \\
\hline $\mathrm{X}_{10}$-Large number of retirees $(0,1)^{12}$ & $1.896^{*}$ & $1.879 *$ & .017 & -.001 & $1.897 * *$ \\
\hline $\begin{array}{l}X_{11} \text { - Presence of senior state college } \\
(0,1)\end{array}$ & .614 & $1.403^{* *}$ & -.090 & .571 & .043 \\
\hline $\mathrm{X}_{12}-\mathrm{Log}$ of distance to nearest SMSA ${ }^{2}$ & $-2.079 * * *$ & $-.842 * *$ & $-1.24 * * *$ & .016 & $-2.095 * * *$ \\
\hline 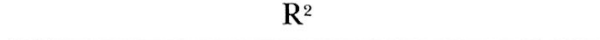 & .28 & .39 & .10 & .22 & .21 \\
\hline
\end{tabular}

ISee Table 3.

${ }^{2}$ Analysis of covariance shows the coefficients in the 1969-73 equation and 1973-79 equation to be significantly different from each other.

*Significant at the $10 \%$ level.

** Significant at the $5 \%$ level.

***Significant at the $1 \%$ level.

All tests of significance are one-tailed. 


\section{Growth in Service Producing and Goods Producing Industries}

Because the demand for the output of service producing industries tends to be local in origin while the demand for the output of goods producing industries can be local, regional, or national, we ran regressions explaining the growth in goods producing and service producing industries separately. As we expected, the two equations are quite different. In both cases, the percent of the population that was Black had a statistically significant negative effect on growth. This effect was of the same order of magnitude for both types of employment. Those variables that could be expected to exert a strong local demand for services such as percent of the population ages 16 to 64 , the presence of air service, a large number of retirees, and the presence of a college all exert a statistically significant influence in employment growth in services industries, but do not appear to influence growth in goods producing industries. On the other hand, the male labor force participation rate is statistically significant for goods producing industries, but not for service producing industries. This suggests that growth in goods producing industries was affected more by local input supply conditions, then by local demand condition.

\section{Employment growth 1969-73 and 1973-79}

Because there were indications that the structure of growth may have changed between the 1969-1973 period and the 1973-1979 period, two final regressions were run to explain employment growth in each of the time periods. The major finding is that while the percent of the population that was Black had a statistically significant effect on county employment growth in the early period, it was not significant in the later period. It appears that there was a decrease in the impact that intercounty racial differences had on employment decisions in the second half of the 1970's.

Table 6 presents a dramatic portrayal of these changes. It shows what would happen to employment growth in the "average county" as percent of the population that is Black is varied from 10 to $90 \%$. During the period 1969-1973, the difference in employment growth between a county $10 \%$ Black and one $90 \%$ Black would be 1000 jobs. This is cut by a factor of five to 200 jobs for the period 1973-79. Thus while race still played a role in determining economic rewards, the effects of intercounty racial differences were greatly diminished.

There are other notable differences between the two periods. The signs on the labor force participation rates alternate between the two periods with the female labor force participation rate having a positive coefficient in the first period and a negative coefficient in the second. The male labor force participation rate coefficient on the other hand is negative in the first period and positive in the second. It is possible that higher female labor force participation rates occur in poorer and, as a result, less skilled counties. If this were the case then as employers looked for a more skilled labor force, they would tend to avoid those areas. If there was a change during the seventies away from low skilled labor then it is conceivable that the coefficient of the female labor force participation rate would change signs during the period. 
TABLE 6

- Employment Growth for “Average County” as Percent Black Varies

\begin{tabular}{ccc}
\hline $\begin{array}{c}\text { Percent } \\
\text { Black }\end{array}$ & $1969-1973$ & $1973-1979$ \\
$10 \%$ & 1082.4 & 1034.7 \\
$20 \%$ & 957.4 & 1009.7 \\
$30 \%$ & 832.3 & 984.6 \\
$40 \%$ & 707.2 & 959.6 \\
$50 \%$ & 582.1 & 934.6 \\
$60 \%$ & 457.1 & 909.6 \\
$70 \%$ & 332.0 & 884.6 \\
$80 \%$ & 206.9 & 859.6 \\
$90 \%$ & 81.9 & 834.6 \\
\hline
\end{tabular}

The coefficients of the variables percent of the population 16 to 64 , large number of retirees, the dummy for the distance of an interstate highway, and the log of the distance to the nearest SMSA are all statistically significant in the second period, but not in the first. Their magnitudes are also different between the two periods. It appears that these variables have become increasingly important in the nonmetro South and have started to overshadow the percent of the population that was Black as major determinants of employment growth.

\section{SUMMARY AND CONCLUSION}

The analysis indicates that employment growth during 1969-79 was much more rapid in the Southern nonmetro counties where Blacks compromised less than 10 percent of the population than in those counties where they compromised more than half of the population. Part, but not all, of this difference can be explained by differences among those county groups in human resource endowments and infrastructure. While differences in growth between the two groups existed throughout the period studies, there is also evidence that as time progressed, the impact that the proportion of the population that was Black had on employment growth declined. That the coefficient on this variable was not significant during the 1973-79 period provides evidence that differences in location decisions based on racial differences may be decreasing. This certainly bears looking into in greater detail.

Our analysis also shows that there appears to be a considerable difference in the structure of growth between goods producing and service producing industries. While the percent of the population that was Black had a relatively similar effect on both types of industry, the growth of service producing industries appears to be driven more by local condition than does the growth of goods producing industries. 
Our results are generally in -accord with those of Walker and others. It appears that the trend of the 1960's towards a lessening in the importance of racial differences in the location decision of industry and an increased desire for skilled workers has continued and intensified during the 1970's. Differences in the quality of the labor force and in infrastructure seem to be of increasing importance in generating employment growth.

Finally, the relatively low $\mathrm{R}^{2 \mathrm{~s}}$ for the regressions indicates that there are other variables that should be examined when looking at employment growth. The paper is a first attempt to look at some of the determinants of economic growth in the nonmetro South, and these preliminary findings indicate that more work on this topic should prove fruitful.

\section{FOOTNOTES}

${ }^{1}$ The six states were Alabama, Arkansas, Georgia, Louisiana, Mississippi, and South Carolina.
${ }^{2}$ Six outlying counties, three with extreme positive growth rates and three with extreme negative growth rates, were dropped from the analysis.

\section{REFERENCES}

1. Beale, Calvin L., "Internal Migration in the United States Since 1970." Statement before the House Select Committee on Population. February 8, 1978 Washington, D.C.: Government Printing Office.

2. Beale, Calvin L., "The Nature and Significance of Recent Population Trends in the South, with Particular Reference to Nonmetropolitan Census," paper prepared for The Poverty Dimensions of Ruralto-Urban Migration (Washington, D.C.: Office of Economic Opportunity and U.S. Dept. of Agriculture, March, 1973).

3. Beale, Calvin L., The Revival of Population Growth in Nonmetropolitan America. Washington, D.C.: U.S. Department of Agricultural, Economics and Statistics Service, Economic Development Division, June 1975.

4. Beale, Calvin L., "Recent Rural Population Trends of Significance to the Professional Agricultural Workers." Paper presented at the Professional Agricultural Workers Conference, Tuskegee Institute, Dec., 1977a.

5. Beale, Calvin L., "The Recent Shift of United States Population to Nonmetropolitan Areas, 1970-75" International Regional Science Review 2 (1977b).

6. Beale, Calvin I., Rural and Small Town Population Change 1970-80. Washington, D.C.: U.S. Department of Agricultural, Economics and Statistics Ser- vice, Economic Development Division, February 1981.

7. Bluestone, Herman, "Employment Growth in Metro and Nonmetro America: A Change in the Pattern?" Agricultural Economic Report, Number 492, Washington, D.C., U.S. Department of Agriculture, Economic Research Service, November, 1982.

8. Miller, James P., "Interstate Highways and Job Growth in Nonmetropolitan Areas: A Reassessment," Transportation Journal (Fall 1979).

9. Persky; Joseph J. and John E. Kain, "Migration, Employment and Race in the Deep South." Southern Economic Journal 36 (1970).

10. Till, Thomas E., "Rural Minorities and Employment Growth, 1959-1977." Unpublished Manuscript.

11. Walker, James L., Economic Development and Black Employment in the Nonmetropolitan South. Austin, Texas: University of Texas at Austin, Bureau of Business Research, 1977.

12. Walker, James L., The Impact of Industrialization on Rural Black Poverty. Working Paper Atlanta Ga: Task Force on Southern Rural Development 1975.

13. Walker, James L., "Industrial Development and Race in the Nonmetropolitan South," The Review of Regional Studies Vol 9, No. 1 (Spring 1979). 